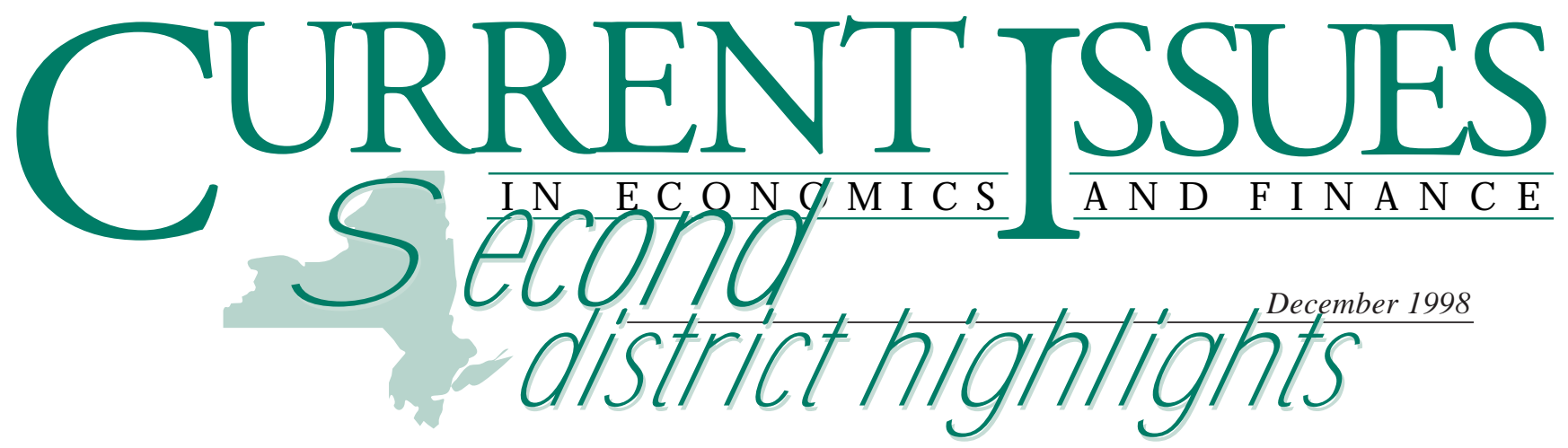

\title{
New York-New Jersey Region's Job Growth to Continue in 1999, but Risks Have Risen
}

The regional employment recovery that began in late 1992 showed no signs of subsiding in 1998. Job growth in the New York-New Jersey region this year is poised to match the 1.7 percent pace of 1997. In New York City, exceptionally strong job growth of 2.3 percent - the second-highest annual growth rate since World War IIis expected to offset the modest deceleration elsewhere in New York State and in New Jersey.

Employment growth will continue in 1999, but the anticipated moderation of the national expansion and an expected cooling down of local financial industry activity will slow it modestly, to about 1.2 percent. Significantly, the uncertain course of securities activity on Wall Street, reflected in recent high-profile announcements of downsizings in major securities firms, opens the possibility of an even greater slowing of financial employment next year than we currently expect. Nevertheless, the region will most likely maintain moderate employment growth overall through 1999.

In this edition of Second District Highlights, we present our forecast for job growth in the New York-New Jersey region in 1999 and compare our forecasts for New York City, New York State, and New Jersey. We also discuss recent developments in the financial industry in New York City and assess the risks to the region posed by a significant further contraction in financial activity.

\section{Job-GrowTH ForECAST}

The first three quarters of 1998 saw a continuation of the regional employment recovery that has been under way for roughly five years, and the full year's growth should reach 1.7 percent, or a little more than 200,000 new jobs (see table). While a diverse group of business and consumer services accounted for more than half of these new jobs, a number of industries-including construction, trade, finance, and segments of the transportation, communications, and public utilities sector-also contributed to the region's generally healthy job growth. Manufacturing employment did slip and government job losses continued, but at a slower rate than in any year of the current recovery.

In 1999, job growth in the region is forecast to slow modestly, to 1.2 percent, yielding roughly 145,000 new jobs. The expected deceleration in the growth of the national economy, though generally anticipated to be moderate, will feed into the region and put some downward pressure on growth. ${ }^{1}$ Nevertheless, considerable momentum remains in three important sectorsservices, trade, and transportation, communications, and public utilities-and jobs there are expected to continue to grow at a pace only somewhat slower than the preceding year's. Moreover, new and ongoing projects will again expand employment in the construction sector, albeit at a reduced rate.

Several sectors of the region's economy will see reduced job levels in 1999. Within the finance, insurance, and real estate (FIRE) sector, employment in New York City's financial industry is projected to decline. Although stock trading volumes are currently healthy, several segments of the securities industry-notably emerging market finance, initial public offerings, and merger and acquisition activity-experienced a setback during the third quarter of $1998 .^{2}$ The slowdown should continue in these segments, causing a modest paring of financial industry employment next year. ${ }^{3}$ Moreover, a decreased demand for financial services will have some negative employment impact on supporting industries such as printing, communications, and business services. The 


\begin{tabular}{|c|c|c|c|c|}
\hline \multicolumn{5}{|c|}{$\begin{array}{l}\text { Employment in the New Yor } \\
\text { Past and Projected Growth } \\
\text { Annual Percentage Change }\end{array}$} \\
\hline & 1996 & 1997 & 1998 & 1999 \\
\hline New York and New Jersey & 0.7 & 1.7 & 1.7 & 1.2 \\
\hline New York State & 0.6 & 1.4 & 1.6 & 1.0 \\
\hline Private sector & 1.0 & 1.8 & 1.9 & 1.3 \\
\hline Public sector & -1.0 & -0.6 & -0.4 & -0.3 \\
\hline New York City & 1.0 & 1.7 & 2.3 & 1.4 \\
\hline Private sector & 1.6 & 2.3 & 2.8 & 1.8 \\
\hline Public sector & -2.1 & -1.4 & -0.9 & -0.9 \\
\hline New Jersey & 1.0 & 2.3 & 2.1 & 1.6 \\
\hline Private sector & 1.3 & 2.8 & 2.6 & 1.9 \\
\hline Public sector & -0.5 & -0.2 & -0.5 & -0.3 \\
\hline
\end{tabular}

Sources: U.S. Department of Labor; Federal Reserve Bank of New York projections.

Note: The 1998 and 1999 figures are projections.

region's banking industry will also see job levels fall, with mergers continuing to lead to employment downsizings. The manufacturing sector will again experience an employment decline as firms resume their long-term job restructuring and relocation, but the pace will be a little below that of previous years. Although government sector downsizings will continue to depress job growth, the rate of decline is expected to slow because the pressures leading to the downsizings of the past several years should abate.

Within the region, the pace of employment growth in 1999 will vary:

- In New York City-the region's star performer through September-job growth will decline from the strong 2.3 percent expected in 1998 to a more modest but still healthy 1.4 percent. The services sector will again lead job creation, followed by the trade, construction, and transportation, communications, and public utilities sectors. Job declines in the region's FIRE sector will be heavily concentrated in New York City, and the drops in the government sector are projected to continue at the pace set in 1998.

- New York State's job growth-at 1.0 percentwill again lag that of New York City as the momentum for growth in the state continues to come largely from the city and downstate urban areas. Only the services sector will add a significant number of new jobs next year in upstate New York.
- New Jersey's job growth will slow mildly, to 1.6 percent, from the 2.1 percent pace expected in 1998. Although moderating growth at the national level will affect New Jersey's performance, employment in business services and construction will still expand at a relatively healthy rate. As in 1998, the main drag on growth will come from declines in manufacturing and government employment.

\section{The Impact of Heightened UnCERTAInTy on WALl Street}

In 1998, the region's securities industry was well on its way to a third consecutive year of record-breaking profits before the markets began to experience turmoil in August. Since then, a slowdown in several lines of business at many securities firms and banks has led to layoffs and touched off reports of potentially large job cutbacks and significant declines in annual bonuses. The heightened uncertainty in the industry is likely to carry over to 1999 , bringing risks to jobs and earnings performance, yet some factors may mitigate these negative effects.

The Near-Term Jobs Impact. Because the region's financial industry remains vulnerable to further shocks from the unusually unsettled international markets, job growth in the industry could slow much more sharply than we currently anticipate. ${ }^{4}$ Our assessment of the impact of a Wall Street slowdown, however, suggests only a small risk of a more significant decline in overall job growth in the region in 1999-mainly because of two offsetting factors.

First, although employment in the financial industry is under pressure, the national economy is still expected to grow moderately next year. This factor should generate a reasonably healthy demand for the region's financial services.

Second, employment expansion should continue at a moderate pace in the region's services sector-which boasts several rapidly growing industries whose nearterm performance is not tied exclusively to the demand for financial services. Employment trends in these industries point to the development of a sizable base of job growth that is unlikely to weaken significantly over the next year. ${ }^{5}$ In the twelve-month period ended September 1998, the regional economy was driven largely by a surge in the demand for services (see chart). It is no surprise, then, that 70 percent of the job growth in New York State and 60 percent of the job gains in New 
York City and New Jersey occurred in the services sector. ${ }^{6}$ In addition, although job growth in securities and commodities firms was cyclically strong through Septemberparticularly in New York State-over the JanuarySeptember period, the region saw nearly three times as many net jobs created in the business services segment

\section{7-98 Contributions by Sector to Job Growth in the New York-New Jersey Region}
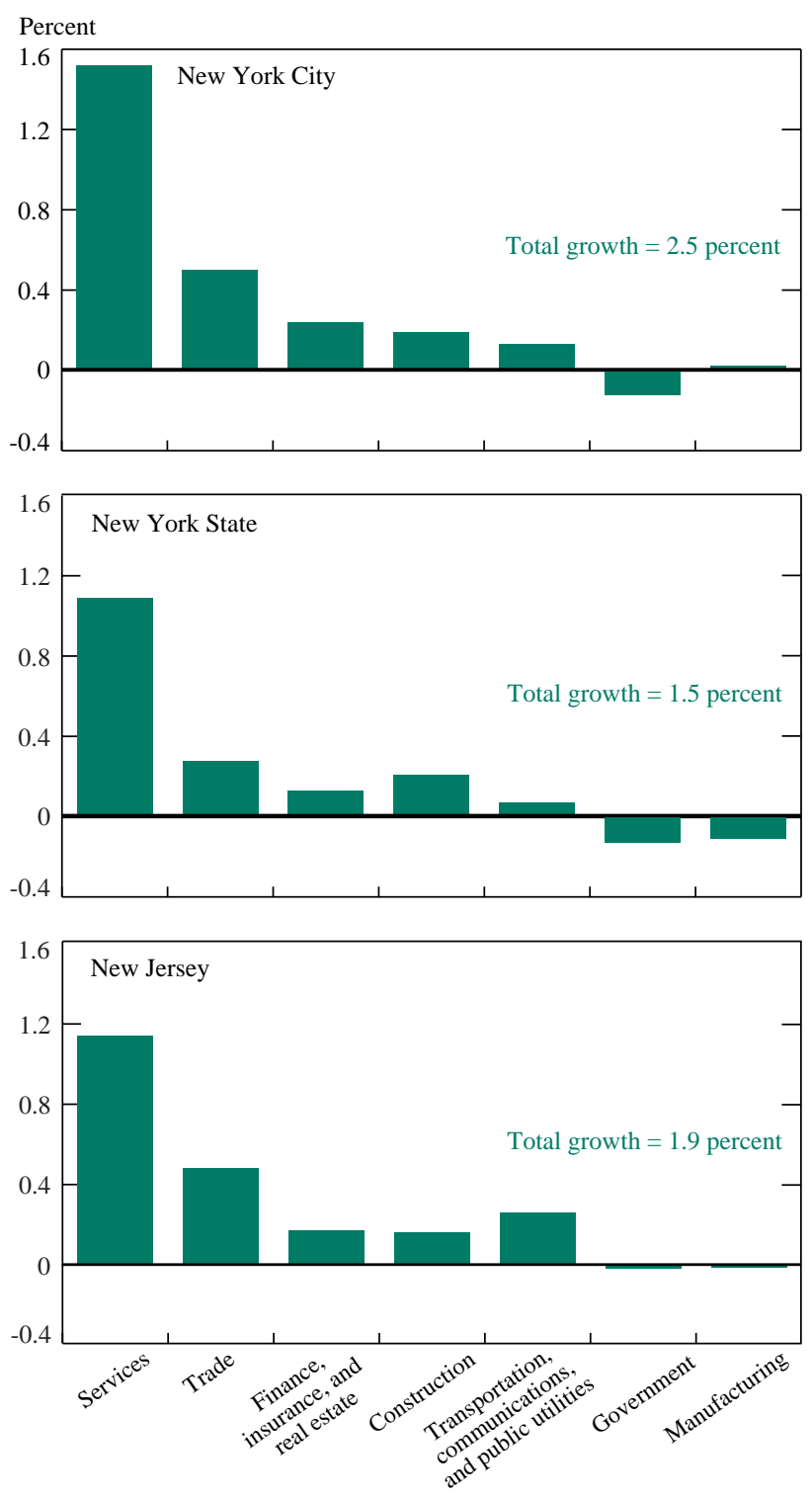

Sources: New York State Department of Labor; New Jersey State Department of Labor.

Note: Figures are from third-quarter 1997 to third-quarter 1998. of the services sector. The engineering and managementconsulting segments of the services sector also made strong contributions to job growth in 1998, and in recent years the tourism, health care, motion picture, and private education segments of the sector have expanded their roles in the region's economy.

The Earnings Impact. Positive employment trends suggest that the region-through its broad job-creation potential - would be somewhat insulated from a decline in financial industry employment in 1999 that was modestly higher than expected. However, a severe decline in jobs-one that would result from a sustained fall in revenues lasting three or four quarters - could have a significant impact on earnings performance in the region. Earnings data show that real wages per worker advanced on average by 1.1 percent per year in New York and New Jersey over the 1989-97 period. Yet if we exclude the highly compensated FIRE sector employees from the calculations, we see that real wages fell 0.4 percent per year in New York and rose by just 0.6 percent in New Jersey. Therefore, a sharp and sustained falloff in financial industry activity could have far-reaching adverse effects on the region. These effects could take the form of a decline in personal and corporate income tax receipts, reduced demand for business services that support the financial industry, and a drop in retail trade activities.

Nevertheless, offsetting factors may soften the impact of an earnings decline in 1999. For instance, any significant reduction in financial industry revenues is unlikely to be felt immediately. A sizable share of income in the industry is paid in the form of annual bonuses in either the fourth quarter of the current calendar year or the first quarter of the new year, implying that most of the income losses related to a severe financial industry decline in 1999 would not kick in until late in the year. Moreover, bonuses generally reflect the full year's performance. Despite the reports of bonus declines, these payments should be fairly strong in 1999 because the industry's first seven months of profits in 1998 were extremely robust, and-despite the August market turmoil—profits are still expected for the fourth quarter.

These factors notwithstanding, the impact of market developments on financial industry earnings will clearly be a pressing issue for the region in 1999. For instance, a full year of subpar performance-three or four quarters of desultory trading, accompanied by a drop in mergers, acquisitions, and initial public offerings-would sharply reduce earnings in this industry and could raise 
questions about a continuation of the region's job recovery in 2000. Significantly, although New York City faces the greatest risk, neither New York State nor New Jersey is immune to the effects of a sustained decline in Wall Street profitability.

\section{Conclusion}

Our outlook for regional job growth in 1999 remains fairly optimistic, with employment growth expected to slow but still to equal or exceed 1 percent in New York City, New York State, and New Jersey. The regional economy is projected to add roughly 145,000 jobs, following a gain of 200,000 jobs in 1998 . We attribute this sustained growth to two factors. First, although national economic growth is expected to slow, it will still be in the neighborhood of 2 percent and thus will not depress regional job growth excessively. Second, key services sector industries such as tourism, private education, and management consulting are expected to remain strong. However, a prolonged decline in such Wall Street businesses as trading, initial public offerings, and mergers and acquisitions could raise questions about the New York-New Jersey region's ability to sustain job growth in 2000. While moderate growth in 1999 remains the most likely prospect, the risks to the region have increased.

\section{- James Orr and Rae D. Rosen}

\section{Notes}

1. GDP growth is forecast to slow to 2.1 percent in 1999 from the 3.4 percent pace expected for 1998 (Blue Chip Consensus Forecast 1998). This slowdown is not expected to cause a significant increase in unemployment.

2. Initial public offering and merger and acquisition activity slowed sharply in the summer and early fall. Recent reports, however, show some pickup in pace. Both activities are significant sources of income and employment in the financial sector and in related business services in the region.

3. Many securities firms have already announced job cutbacks. For example, on October 13, Merrill Lynch reported its plan to reduce employment by 3,400 full-time workers and 900 full-timeequivalent consultants. The cutbacks are to be accomplished through a combination of severance and attrition, although the exact timing has not been specified. About half of the affected employees work in the New York-New Jersey region, with roughly an equal number in each state. Potential job cuts at other financial institutions in the region have also been reported, but the exact number of cuts and the extent to which the reductions will be accomplished through attrition have not been indicated.

4. Financial industry employment in the region is expected to be flat in 1999 compared with the 1.5 percent growth expected in 1998 and the 0.9 percent growth recorded in 1997. In New York City, financial industry employment is expected to decline by about 1.0 percent in 1999 after expanding by 1.4 percent in 1998 .

5. For example, see Bram and De Mott (1998) for a discussion of job growth in the new-media industry and in traditional media industries in New York City, and Bram (1995) for a description of the tourism industry's role in the region.

6. This trend continues the pattern of job growth seen throughout this recovery. See Orr and Rosen (1997).

\section{REFERENCES}

Blue Chip Consensus Forecast. 1998. Vol. 23, no. 11, November 10.

Bram, Jason. 1995. "Tourism and New York City's Economy." Federal Reserve Bank of New York Current Issues in Economics and Finance 1, no. 7 (October).

Bram, Jason, and Mike De Mott. 1998. "New York City's New-Media Boom: Real or Virtual?" Federal Reserve Bank of New York Current Issues in Economics and Finance 4, no. 10 (October).

Orr, James, and Rae D. Rosen. 1997. “The New York-New Jersey Job Recovery." Federal Reserve Bank of New York Current Issues in Economics and Finance 3, no. 12 (October).

The views expressed in this article are those of the authors and do not necessarily reflect the position of the Federal Reserve Bank of New York or the Federal Reserve System.

Second District Highlights, a supplement to Current Issues in Economics and Finance, is published by the Research and Market Analysis Group of the Federal Reserve Bank of New York. Dorothy Meadow Sobol is the editor.

Editorial Staff: Valerie LaPorte, Mike De Mott, Elizabeth Miranda

Production: Carol Perlmutter, Lingya Dubinsky, Jane Urry

Subscriptions to Second District Highlights are free. Write to the Public Information Department, Federal Reserve Bank of New York, 33 Liberty Street, New York, N.Y. 10045-0001, or call 212-720-6134. Second District Highlights is also available at the Research and Market Analysis Group's web site: http://www.ny.frb.org/rmaghome/curr_iss/sec_dis. 